\title{
Nurmisäilörehun D-arvon ja väkirehun valkuaispitoisuuden vaikutus hereford-sonnien loppukasvatuksessa a) Tuotantotulokset sekä ruhon ja lihan laatu
}

\author{
Merja Manninen ${ }^{1)}$, Arja Nykänen ${ }^{2)}$, Lauri Jauhiainen ${ }^{1)}$ ja Päivi Volanto ${ }^{3)}$ \\ ${ }^{1)}$ MTT, 31600 Jokioinen, merja.manninen@mtt.fi, lauri.jauhiainen@mtt.fi \\ ${ }^{2)}$ MTT, 51900 Juva, arja.nykänen@mtt.fi \\ 3) Rehuraisio Oy, paivi.volanto@raisiogroup.com
}

\section{Tiivistelmä}

Nautojen ruokinnassa sulavan orgaanisen aineen määrä rehun kuiva-aineessa eli D-arvo on Suomessa tärkein karkearehun ravitsemuksellista laatua kuvaava tekijä. Tämä tutkimus selvitti nurmisäilörehun D-arvon ja väkirehun valkuaispitoisuuden vaikutukset hereford (hf)-sonnien kasvuun, rehun muuntosuhteeseen, ruhojen luokittumiseen, lihan aistinvaraiseen laatuun ja arvopalojen saantoon vieroituksen jälkeisessä kasvatuksessa.

Kokeeseen otettiin 32 hf-sonnia, jotka kokeen alkaessa painoivat keskimäärin 288 kg. Koe tehtiin MTT:n emolehmänavetalla, jossa eläimet olivat neljän eläimen karsinoissa. Koemalli oli $2 * 2$ faktoriaalinen, faktoreina säilörehun D-arvo (A; 75 \% vs. B; 70 \%) ja väkirehun valkuaispitoisuus (M; 17 \% vs. H; 21 \%). Säilörehu niitettiin niittomurskaimella ja korjattiin tarkkuussilppurilla laakasiiloon. Väkirehuna oli ohran ja valkuaispuolitiivisteen seos. Sonnit saivat väkirehua ensimmäiset 56 pv 2,0, seuraavat 57 pv 3,0 ja loppukasvatuksen ajan 4,0 kg KA/pv. Eläimet saivat kivennäistä, mutta eivät vitamiinia. Dieetin sulavuus määritettiin kahdesti kokeen aikana. Sonnit teurastettiin Lihakunnan Kuopion teurastamossa ja lihan aistinvarainen arviointi tehtiin LTK:ssa.

A:n KA-pitoisuus oli keskimäärin $251 \mathrm{~g} / \mathrm{kg}$ ja D-arvo 75,0 \%. KA-kilo sisälsi raakavalkuaista 162 g, OIV:sta 91 g ja ND-kuitua 418 g. Vastaavat luvut B:lle olivat 307 g/kg, 69,9 \%, 151 g, 86 g ja 483 g. Säilörehujen apilapitoisuus oli 25-30 \% KA:sta. Ohran valkuaispitoisuus oli keskimäärin 143 g/kg KA ja energiapitoisuus 1,12 RY, puolitiivisteelle vastaavat arvot olivat 289 g/kg KA ja 1,02 RY. Säilörehun syönti oli yhdenmukainen kaikilla käsittelyillä ja jaksoilla. Koko kokeelle laskettuna väkirehu-\% oli keskimäärin 34. Kaikki ruokinnat täyttivät luonnonmukaisen tuotannon vaatimukset väkirehu-karkearehu-suhteesta. Sonnien tavoite-elopaino ennen teurastusta oli $600 \mathrm{~kg}$. Viidellä sonnilla mainittu tavoite jäi saavuttamatta. Tavoiteteuraspaino $330 \mathrm{~kg}$ saavutettiin ainoastaan AHkäsittelyllä. Teuraspaino oli keskimäärin 325 kg. Säilörehun korjuuaste ja sitä kautta rehun sulavuus vaikutti merkitsevästi kokeen kestoon ollen A:lla keskimäärin 17 pv lyhyempi kuin B:llä. A-sonnit kasvoivat B-sonneja paremmin (1795 vs. 1609 g/pv). Teuras-\%, ruhon lihakkuus ja rasvaluokka olivat keskimäärin 53,7, 6,5 ja 3,6. Dieetin OA:n ja NDF:n sulavuus oli A-sonneilla merkitsevästi parempi kuin B-sonneilla, mikä selittää parhaiten A-sonnien parempaa kasvutulosta. Ruokintojen vaikutus lihan aistinvaraiseen laatuun oli vähäinen. Kaikkien ruhojen tervaliha-\% oli 0. Käsittelyiden vaikutus arvopalojen ja talin leikkuusaantoon oli marginaalinen.

Kaikkien sonnien kasvu oli erinomaista. Hyvän säilörehun merkitys lihanaudan tehokkaassa kasvatuksessa korostui ja D-arvon nousu 70 \%:sta viidellä \%-yksiköllä paransi sonnien kasvua vielä huomattavasti. Väkirehun valkuaispitoisuus ei tässä kokeessa vaikuttanut tuotantotuloksiin eikä ruhojen rasvaluokkiin. Kokeen tulokset ovat sovellettavissa myös luomulihantuotantoon.

Avainsanat: säilörehu, lihan laatu, naudanlihantuotanto, ruokinta, sonni 


\section{Johdanto}

Nautojen ruokinnassa sulavan orgaanisen aineen määrä rehun kuiva-aineessa eli D-arvo on Suomessa tärkein karkearehun ravitsemuksellista laatua kuvaava tekijä. D-arvon vaikutusta lypsylehmien maidontuotantoon on tutkittu runsaasti (Rinne 2000, Kuoppala ym. 2004). Sen sijaan D-arvon vaikutusta naudanlihantuotantoon on Suomessa tutkittu vähän tai aiemmin maitorotuisilla sonneilla huomattavasti alhaisemmassa elopainossa (Aronen ym. 1992). Hyvän säilörehun merkitys naudanlihantuotannossa on kuitenkin kiistaton. Tohmajärven emolehmänavetalla tehtiin hereford (hf)sonneilla aiemmin koe, jossa sonnit söivät väkirehua keskimäärin 38 \% kuiva-aineesta (KA) väkirehun valkuaispitoisuuden ollessa 21 \% KA:ssa ja nurmisäilörehua, jonka D-arvo oli 70 \%. Sonnit saavuttivat vajaan 14 kuukauden iässä 639 kilon elopainon ja ruhojen rasvaluokka oli keskimäärin 3,2. Päiväkasvu vieroituksesta teurastukseen oli erinomainen eli keskimäärin 1557 g (Manninen ym. 2004).

Tämän tutkimuksen tavoitteena oli selvittää nurmisäilörehun D-arvon ja väkirehun valkuaispitoisuuden vaikutus hf-sonnien kasvuun, rehun muuntosuhteeseen, ruhojen luokittumiseen, lihan aistinvaraiseen laatuun ja arvopalojen saantoon vieroituksen jälkeisessä kasvatuksessa. Alkuperäisenä tavoitteena oli käyttää kokeessa hyvän ja huonohkon D-arvon (69 ja 64 \%) omaavia säilörehuja, mutta kasvukauden edetessä toivottua D-arvon alenemista kasvustossa Pohjois-Karjalan olosuhteissa ei kuitenkaan tapahtunut. Näin kokeeseen saatiin korkean ja hyvän D-arvon (75 ja 70 \%) omaavat puna-apila/heinä-säilörehut. Sonnit saivat kahden eri valkuaispitoisuuden, 17 ja 21 \% KA:ssa, väkirehuseosta 2-4 kg KA/eläin päivässä. Väkirehun annostus toteutettiin siten, että se täytti luonnonmukaisen tuotannon vaatimuksen väkirehu:karkearehu -suhteesta (40:60). Myös eläinten alkukasvatus, emon kanssa ensimmäiset kuusi kuukautta, ja loppukasvatusolosuhteet täyttivät luonnonmukaisen tuotannon edellytykset, joten tulokset ovat sovellettavissa luomunaudanlihantuotantoon, vaikka eläimet ja rehut eivät alkuperältään ole peräisin luonnonmukaisesta tuotannosta. Alle vuoden ikäisten sonnien laiduntamispakko ei koskenut kokeen eläimiä, jotka teurastettiin ennen toista laidunkautta. Sonnien teuraspainotavoitteeksi asetettiin liharotuisille sonneille kenties hieman alhainen 330 kiloa, koska koerehuja saatiin kasvukauden poikkeuksellisista olosuhteista johtuen arvioitua vähemmän. MTT/Taloustutkimus vertaili ruokintojen taloudellisuutta.

\section{Aineisto ja menetelmät}

\section{Eläinaines ja tuotanto-olosuhteet}

Kokeeseen otettiin 32 MTT:n emolehmänavetalla 13.3.-10.6.2003 syntynyttä hf-sonnivasikkaa, joiden isät olivat hf-sonnit Innilän Leevi (15), Koskis Noak (9), Karjasuon Pölli (7) ja Karjasuon Paukku (1). Vasikoiden päiväkasvu ennen koetta oli keskimäärin 1093 g. Ennen koetta vasikat olivat emineen laitumella eivätkä saaneet siellä väkirehua. Koe alkoi 19.11.2003 vasikoiden ollessa keskimäärin 7,4 (SD 0,73) kuukauden ikäisiä ja 288 (SD 37,5) kilon painoisia. Koe tehtiin MTT:n emolehmänavetalla, jossa eläimet olivat neljän eläimen karsinoissa. Eläimet ulkoilivat jaloittelutarhoissa karsinoiden kuivituksen ajan. Sonnit punnittiin säännöllisesti ja niiden terveydentilaa seurattiin.

\section{Rehut, ruokinta ja teurastus}

Koemalli oli 2*2 faktoriaalinen, jossa faktoreina olivat säilörehun D-arvo (korkea 75 \%, A vs. hyvä 70 \%, B) ja väkirehun valkuaispitoisuus (medium 17 \%, M vs. high $21 \%$, H). Karkearehuksi korjattiin toisen vuoden nurmesta (siemenseoksessa timotei-nurminata-puna-apila 65-30-5 \%) ensimmäisen niiton sato, jota oli keväällä lannoitettu $20-50 \mathrm{~kg} \mathrm{~N} / \mathrm{ha}$. Kasvustosta otettiin ennakkonäytteet 17.6. ja 30.6., joista määritettiin puna-apilan osuus sekä analysoitiin raakavalkuaispitoisuus sekä D-arvo kasvilajeittain Valion laboratoriossa NIRS-analysaattorilla. Näin pyrittiin optimoimaan rehun korjuuaika. Säilörehut niitettiin Elho-niittomurskaimella ja korjattiin JF 900-tarkkuussilppurilla laakasiiloon. Rehujen säilöntään käytettiin AIV 2 Plus -liuosta (760 g muurahaishappoa/kg ja 55 g ammoniumformiaatti/kg) 5 litraa rehutonnille. Säilörehu A:n kasvusto niitettiin ja korjattiin 17.18.6.2003 ja säilörehu B:n kasvusto 30.6.-2.7.2003. Syötetyistä rehuista määritettiin KA, raakaproteiini, tuhka, orgaanisen aineen (OA) in vitro-sellulaasisulavuus (Friedel 1990), rehujen säilönnällinen laatu, D-arvo ja NDF-pitoisuus (Van Soest ym. 1991).

Väkirehuna oli ohran ja valkuaispuolitiivisteen (Rehuraisio Oy: FUTURA-MAITURI 140 L) seos, jonka raakavalkuaispitoisuudeksi asetettiin joko $17 \%$ tai $21 \%$ KA:ssa. Valkuaistiiviste sisälsi 
rypsipuristetta $68,0 \%$, vehnälesettä $10,5 \%$, melassileikettä 7,0 \%, seosmelassia 5,0 \%, vehnärehujauhoa 4,2 \%, kauralesettä 3,0 \%, kalsiumkarbonaattia 1,1 \%, natriumkloridia 0,6 \% ja esiseoksia 0,6 \% tuorepainosta. Sonnit saivat väkirehua ensimmäiset 56 päivää 2,0 (alkujakso), seuraavat 57 päivää 3,0 (keskijakso) ja loppukasvatuksen (keskimäärin 74 päivää, SD 22,2) ajan 4,0 kg KA/pv. Eläimet saivat kivennäisenä Luonnon Viher-Mineraa (Ca 84, P 34, Na 60 ja Mg 70 g/kg) ja vettä vapaasti. Vitamiinia eläimet eivät saaneet. Väkirehun rehuarvo laskettiin raaka-ainekoostumuksen perusteella (MTT 2004). Dieetin sulavuus määritettiin kahdesti kokeen aikana, kerran keski- ja kerran loppujaksolla käyttäen merkkiaineena happoon liukenematonta tuhkaa (European Commission 1971). Sonnit teurastettiin Lihakunnan Kuopion teurastamossa, ruhojen arvopalat ja rasva punnittiin erikseen ja ruhot luokitettiin EUROP-luokituksen mukaisesti. Lihan aistinvarainen arviointi tehtiin LTK:ssa.

\section{Tilastollinen käsittely}

Eläimet jaettiin koon mukaan kahteen lohkoon. Lohkon sisällä eläimet arvottiin neljään karsinaan, joihin kuhunkin kohdistettiin yksi käsittelyistä. Syönti ja sulavuus mitattiin karsinakohtaisesti, jolloin standardia satunnaistettujen täydellisten lohkojen varianssianalyysiä pystyttiin käyttämään käsittelyiden välisten erojen testauksessa. Muut muuttujat mitattiin eläinkohtaisesti. Koska käsittelyt kohdistettiin karsinoihin, ei eläimiin, eläinten välistä vaihtelua ei voitu käyttää virheterminä käsittelyiden välisiä eroja testattaessa. Käytettäväksi valitun tilastollisen mallin on esittänyt mm. Morris (1999) ja siinä virheterminä on lohko 'nested' käsittely -tekijä. Analyysit suoritettiin SAS:n (1999) versiolla 8.2.

\section{Tulokset ja tulosten tarkastelu}

Rehujen kemiallinen koostumus ja rehuarvo esitetään Taulukossa 1. Säilörehujen apilapitoisuus oli 2530 \% KA:sta. Yksi BM-eläin poistettiin kokeesta 26.1.2004 jalan revähtymän ja siitä seuranneen liikuntavaikeuden johdosta. Muiden eläinten terveys oli moitteeton eikä kliinisiä oireita havaittu. Säilörehun syönti oli yhdenmukainen kaikilla käsittelyillä kaikilla jaksoilla (Taulukko 2). Väkirehun valkuaispitoisuudet olivat asetettujen tavoitteiden mukaiset. Loppukasvatuskaudella väkirehun osuus syönnistä oli AM-, AH- ja BH-sonneilla 38 \% ja BM-sonneilla 39 \%. Koko koekaudelle laskettuna väkirehuprosentti oli AM-, AH-, BM- ja BH-käsittelyille vastaavasti 34, 34, 34 ja 33 ja dieetin valkuaispitoisuus vastaavasti 16, 18, 15 ja 17 \% KA:ssa. Kaikki ruokinnat täyttivät luonnonmukaisen tuotannon vaatimukset väkirehu-karkearehu-suhteesta hyvin. Väkirehun annostus olisi siten voinut olla jopa hieman suurempikin mainitulla ehdolla. Rehu A ei riittänyt aivan kokeen loppuun asti, mutta täydennykseksi saatiin Kiteen oppimiskeskuksen pellolta korjattua luomusäilörehua, jonka D-arvo oli kokeeseen hyvin sopiva, 75,4 \%, mutta valkuaispitoisuus alhaisempi kuin varsinaisen koerehun (134 vs. $173 \mathrm{~g} / \mathrm{kg} \mathrm{KA}$ ).

Tavoitteena oli, että kaikkien sonnien elopaino oli 600 kiloa ennen teuraaksi lähtöä. Viidellä sonnilla mainittu tavoite jäi saavuttamatta. Tavoiteteuraspaino 330 kiloa saavutettiin ainoastaan AHkäsittelyllä, muilla käsittelyillä siitä jäätiin keskimäärin seitsemän kiloa (Taulukko 3). Keskimääräiseksi teuraspainoksi muodostui 325 kiloa. Säilörehun korjuuaste eli sulavuus/määrä vaikutti merkitsevästi kokeen kestoon ollen A-rehulla keskimäärin 17 päivää lyhyempi kuin B-rehulla $(\mathrm{P}<0,01$, 179 vs. 196 pv). A-sonnit kasvoivat alku- ja loppujaksolla B-sonneja hieman paremmin (alkujakso: $\mathrm{P}<0,10,1817$ vs. 1524 g/pv ja loppujakso: $\mathrm{P}<0,10,1816$ vs. 1628 g/pv). Keskijaksolla päiväkasvujen välillä ei ilmennyt tilastollisesti merkitseviä eroja kasvun ollessa keskimäärin 1716 g. Koko kasvatuskaudelle laskettuna A-sonnit kasvoivat päivässä 186 g paremmin $(\mathrm{P}<0,01,1795$ vs. 1609 g/pv) kuin B-sonnit. A-sonnien nettokasvu ylitti kilon ollen keskimäärin 1028 g/pv, kun se B-sonneilla oli keskimäärin $912 \mathrm{~g} / \mathrm{pv}(\mathrm{P}<0,05)$. Teurasprosentti, ruhon lihakkuus ja rasvaluokka olivat keskimäärin 53,7 \%, 6,5 ja 3,6. Rehun muuntosuhde lisäkasvukiloa kohden oli A-sonneilla B-sonneja parempi ( $\mathrm{P}<0,05,5,26$ vs. 5,93 kg KA), energian suhteen ero oli suuntaa antava ( $\mathrm{P}<0,10,5,33$ vs. 5,76 RY). 
Taulukko 1. Rehujen kemiallinen koostumus ja rehuarvo.

\begin{tabular}{|c|c|c|c|c|c|}
\hline Rehu & Säilörehu A & Säilörehu B & Ohra & Valkuaistiiviste & Kivennäinen \\
\hline Näytteiden lukumäärä & 4 & 4 & 1 & 1 & 1 \\
\hline \multicolumn{6}{|l|}{ Kemiallinen koostumus } \\
\hline Kuiva-aine (KA, g/kg) & 251 & 307 & 879 & 881 & 968 \\
\hline \multicolumn{6}{|l|}{ KA:ssa (g/kg) } \\
\hline Tuhka & 76 & 85 & 29 & 88 & 550 \\
\hline Raakavalkuainen & 162 & 151 & 143 & 289 & 67 \\
\hline Raakarasva & $n d^{\mathrm{a}}$ & nd & 20 & 84 & nd \\
\hline Raakakuitu & nd & nd & 55 & 121 & nd \\
\hline Neutraali detergentti kuitu & 418 & 483 & 226 & 313 & 97 \\
\hline Maitohappo & 73 & 45 & & & \\
\hline Etikkahappo & 28 & 18 & & & \\
\hline Voihappo & 0,40 & 0,38 & & & \\
\hline Etanoli & 8,0 & 4,4 & & & \\
\hline Sokeri & 26 & 52 & & & \\
\hline $\mathrm{pH}$ & 3,78 & 4,03 & & & \\
\hline \multicolumn{6}{|l|}{ Kokonaistypessä (g/kg) } \\
\hline Ammonium-N & 40 & 45 & & & \\
\hline Liukoinen-N & 511 & 547 & & & \\
\hline D-arvo & 75,0 & 69,9 & & & \\
\hline Syönti-indeksi & 108 & 103 & & & \\
\hline \multicolumn{6}{|l|}{ Rehuarvo, /kg KA } \\
\hline RY & 1,03 & 0,96 & 1,12 & 1,02 & \\
\hline OIV, g & 91 & 86 & 107 & 137 & \\
\hline Pötsin valkuaistase, g & 7 & 4 & -32 & 77 & \\
\hline
\end{tabular}

"Ei määritetty.

OIV, ohutsuolesta imeytyvä valkuainen (aminohapot).

Taulukko 2. Rehujen syönti ja energian saanti.

\begin{tabular}{|c|c|c|c|c|c|c|c|c|}
\hline \multirow{2}{*}{$\begin{array}{l}\text { Säilörehu (S) } \\
\text { Väkirehun valk.pitoisuus, (V) }\end{array}$} & \multicolumn{2}{|c|}{ A } & \multicolumn{2}{|c|}{$\mathrm{B}$} & \multicolumn{4}{|c|}{ Merkitsevyys $^{2}$} \\
\hline & M & $\mathrm{H}$ & M & $\mathrm{H}$ & SEM $^{1}$ & $\mathrm{~S}$ & $\mathrm{~V}$ & $\mathrm{~S} * \mathrm{~V}$ \\
\hline Ryhmiä & 2 & 2 & 2 & 2 & & & & \\
\hline \multicolumn{9}{|l|}{ Säilörehu, kg KA } \\
\hline Alkujakso & 5,48 & 5,77 & 5,23 & 5,44 & 0,237 & & & \\
\hline Keskijakso & 5,87 & 5,86 & 6,22 & 6,67 & 0,305 & & & \\
\hline Loppujakso & 6,16 & 6,18 & 6,02 & 6,20 & 0,183 & & & \\
\hline Keskimäärin & 5,88 & 5,98 & 5,86 & 6,13 & 0,157 & & & \\
\hline Ohra, kg KA keskim. & 2,55 & 1,71 & 2,60 & 1,73 & 0,015 & & $* * *$ & \\
\hline Tiiviste, kg KA keskim. & 0,58 & 1,45 & 0,59 & 1,47 & 0,003 & $*$ & $* * *$ & \\
\hline Kivennäinen, kg KA keskim. & 0,28 & 0,29 & 0,28 & 0,28 & 0,001 & & & \\
\hline \multicolumn{9}{|l|}{ Yhteensä, kg KA } \\
\hline Alkujakso & 7,75 & 8,04 & 7,50 & 7,71 & 0,238 & & & \\
\hline Keskijakso & 9,14 & 9,15 & 9,51 & 9,95 & 0,306 & & & \\
\hline Loppujakso & 10,40 & 10,51 & 10,32 & 10,50 & 0,163 & & & \\
\hline Keskimäärin & 9,30 & 9,43 & 9,34 & 9,61 & 0,149 & & & \\
\hline Raakavalkuainen, g & 1518 & 1666 & 1443 & 1611 & 19,8 & $*$ & $* *$ & \\
\hline $\mathrm{OA}, \mathrm{kg}$ & 8,58 & 8,64 & 8,57 & 8,76 & 0,137 & & & \\
\hline NDF, $g$ & 3250 & 3372 & 3637 & 3842 & 72,1 & $* *$ & & \\
\hline $\mathrm{RY}$ & 9,48 & 9,52 & 9,12 & 9,29 & 0,144 & & & \\
\hline OIV,g & 890 & 928 & 862 & 911 & 12,6 & & $*$ & \\
\hline
\end{tabular}

${ }^{1}$ Keskiarvon keskivirhe.

${ }^{2}$ o $\mathrm{P}<0,10$; * $\mathrm{P}<0,05$; ** $\mathrm{P}<0,01$; *** $\mathrm{P}<0,001$. 
Taulukko 3. Sonnien kasvu, teurastulokset ja rehun muuntosuhde. Säilörehu (S) A $\mathrm{B}$

\begin{tabular}{|c|c|c|c|c|c|c|c|c|}
\hline \multirow{2}{*}{$\begin{array}{l}\text { Säilörehu (S) } \\
\text { Väkirehun valk.pitoisuus, (V) }\end{array}$} & \multicolumn{2}{|c|}{ A } & \multicolumn{2}{|c|}{ B } & \multirow[b]{2}{*}{ SEM $^{1}$} & \multicolumn{3}{|c|}{ Merkitsevyys $^{2}$} \\
\hline & M & $\mathrm{H}$ & M & $\mathrm{H}$ & & $\mathrm{S}$ & V & $\mathrm{S} * \mathrm{~V}$ \\
\hline Eläinten lukumäärä & 8 & 8 & $8^{a}$ & 8 & & & & \\
\hline Elopaino kokeen lopussa, kg & 604 & 610 & 601 & 606 & $3,8-4,1$ & & & \\
\hline Teuraspaino, kg & 324 & 331 & 321 & 324 & $4,1-4,4$ & & & \\
\hline Kokeen kesto, pv & 179 & 179 & 198 & 195 & $1,8-2,0$ & $* *$ & & \\
\hline Kasvu, alkujakso, g/pv & 1719 & 1915 & 1430 & 1617 & $110,0-118,8$ & 0 & & \\
\hline keskijakso, g/pv & 1804 & 1713 & 1723 & 1622 & $69,5-75,1$ & & & \\
\hline loppujakso, g/pv & 1799 & 1833 & 1610 & 1646 & 73,7-79,6 & 0 & & \\
\hline keskimäärin, g/pv & 1782 & 1809 & 1588 & 1630 & $22,1-23,9$ & $* *$ & & \\
\hline Nettokasvu, g/pv & 1009 & 1048 & 902 & 923 & $20,2-21,8$ & $*$ & & \\
\hline Teuras-\% & 53,6 & 54,3 & 53,5 & 53,5 & $0,38-0,41$ & & & \\
\hline Lihakkuus $^{4}$ & 6,5 & 6,6 & 6,0 & 6,6 & $0,34-0,36$ & & & \\
\hline Rasvaisuus $^{5}$ & 3,5 & 3,6 & 3,3 & 3,9 & $0,17-0,19$ & & & \\
\hline Kg KA / lisäkasvu-kg & 5,26 & 5,25 & 5,92 & 5,94 & $0,151-0,163$ & $*$ & & \\
\hline Kg KA / nettokasvu-kg & 9,29 & 9,04 & 10,45 & 10,49 & $0,320-0,346$ & $*$ & & \\
\hline RY / lisäkasvu-kg & 5,36 & 5,30 & 5,78 & 5,74 & $0,142-0,153$ & 0 & & \\
\hline RY / nettokasvu-kg & 9,46 & 9,13 & 10,19 & 10,13 & $0,307-0,331$ & $\mathrm{o}$ & & \\
\hline RV / lisäkasvu-kg & 859 & 929 & 914 & 996 & $21,7-23,5$ & 0 & $*$ & \\
\hline RV / nettokasvu-kg & 1516 & 1597 & 1613 & 1758 & $49,9-53,9$ & $\mathrm{o}$ & & \\
\hline
\end{tabular}

${ }^{1}$ Keskiarvon keskivirhe. $\quad{ }^{2}$ o $\mathrm{P}<0,10$; * $\mathrm{P}<0,05$; ** $\mathrm{P}<0,01$; *** $\mathrm{P}<0,001$.

${ }^{3}$ Nettokasvua laskettaessa alkupainon teuras-\%:na käytetty 50.

${ }^{4}$ EUROP-luokitus: O-=4, O=5, O+=6, R-=7, R=8, R+=9.

${ }^{5}$ EUROP-luokitus: 2=vähäinen, 3=keskinkertainen, 4=rasvainen.

${ }^{\circledR}$ Yksi eläin poistettiin kokeesta 26.1.2004 jalan revähtymän ja sitä seuranneen liikuntavaikeuden johdosta.

Dieetin OA:n ja NDF:n sulavuus oli A-sonneilla merkitsevästi parempi kuin B-sonneilla ( $\mathrm{P}<0,05,76,9$ vs. 73,3 \% ja 66,5 vs. 62,5 \%), mikä selittää parhaiten A-sonnien parempaa kasvutulosta (Taulukko 4). Proteiinin kohdalla ero oli suuntaa antava $(\mathrm{P}<0,10,69,7$ vs. 66,7). Käsittelyfaktoreiden välillä ilmeni tilastollisesti merkitsevä yhdysvaikutus $(\mathrm{P}<0,05)$ OA:n sulavuudessa siirryttäessä keskijaksolta loppujaksolle. A-sonneilla OA:n sulavuus parani väkirehun korkeammalla valkuaispitoisuudella vaikutuksen ollessa päinvastainen $B$-sonneilla. Vastaava yhdysvaikutus $(P<0,05)$ todettiin myös NDF:n kohdalla.

Ruokintojen vaikutus lihan aistinvaraiseen laatuun oli, monien aikaisempien kokeiden tapaan, vähäinen (Taulukko 5). Väkirehun matalampi proteiinipitoisuus A-säilörehulla paransi $(\mathrm{P}<0,05)$ lihan mureutta, kun vaikutus B:llä oli päinvastainen. B-lihan maku arvioitiin hieman paremmaksi kuin Alihan maku ( $\mathrm{P}<0,10,4,9$ vs. 4,4). Mehukkuuden arvio oli keskimäärin 4,5 ja konsistenssin 8,5. Kaikkien ruhojen ulkofileen loppu-pH oli alle 6,00 eli tervalihaprosentti oli 0 . Käsittelyiden vaikutus arvopalojen ja talin leikkuusaantoon oli myös marginaalinen (Taulukko 6). A-rehulla ulkopaistin ja kulmapaistin saannot muodostuivat hieman paremmiksi kuin B-rehulla (UP: $\mathrm{P}<0,10,18,2$ vs. 17,5 kg ja KP: $\mathrm{P}<0,05,10,6$ vs. 10,1 kg). Sisäfilettä ruhon puolikkaasta leikattiin keskimäärin 4,0 kg, ulkofilettä $10,3 \mathrm{~kg}$ ja rasvaa $34,5 \mathrm{~kg}$.

Taulukko 4. Dieetin orgaanisen aineen (OA), proteiinin ja NDF:n sulavuus keskimäärin kahdella jaksolla ja sulavuuden muutos keskijaksoilta loppujaksolle.

\begin{tabular}{|c|c|c|c|c|c|c|c|c|}
\hline \multirow{2}{*}{\multicolumn{2}{|c|}{$\begin{array}{l}\text { Säilörehu, (S) } \\
\text { Väkirehun valkuaispitoisuus, (V)M }\end{array}$}} & & \multicolumn{2}{|c|}{ B } & \multirow[b]{2}{*}{ SEM $^{1}$} & \multicolumn{3}{|c|}{ Merkitsevyys $^{2}$} \\
\hline & & $\mathrm{H}$ & M & $\mathrm{H}$ & & S & V & $\mathrm{S} * \mathrm{~V}$ \\
\hline Ryhmien lukumäärä & 2 & 2 & 2 & 2 & & & & \\
\hline \multicolumn{9}{|l|}{ Sulavuus, \% } \\
\hline Orgaaninen aine & 76,6 & 77,3 & 73,4 & 73,2 & 0,67 & $*$ & & \\
\hline Proteiini & 69,1 & 70,3 & 65,6 & 67,7 & 1,04 & 0 & & \\
\hline$N D F$ & 64,2 & 68,8 & 61,9 & 63,2 & 1,12 & * & o & \\
\hline \multicolumn{9}{|c|}{ Muutos keskijaksolta loppujaksolle } \\
\hline $\mathrm{OA}$ & $-0,13$ & 4,85 & $-0,61$ & $-1,56$ & 0,867 & * & & $*$ \\
\hline Proteiini & 1,91 & 5,35 & 0,05 & $-1,03$ & 1,725 & 0 & & \\
\hline NDF & $-0,94$ & 9,83 & 1,34 & $-0,13$ & 1,720 & & 0 & $*$ \\
\hline
\end{tabular}

\footnotetext{
${ }^{1}$ Keskiarvon keskivirhe. ${ }^{2}$ o $\mathrm{P}<0,10$; * $\mathrm{P}<0,05 ; * * \mathrm{P}<0,01 ; * * * \mathrm{P}<0,001$
} 
Taulukko 5. Lihan aistinvarainen laatu ja pH.

\begin{tabular}{lccccccc} 
Säilörehu, (S) & \multicolumn{2}{c}{$\mathrm{A}$} & \multicolumn{2}{c}{$\mathrm{B}$} & \multicolumn{2}{c}{ Merkitsevyys $^{2}$} \\
Väkirehun valk.pitoisuus, (V) & $\mathrm{M}$ & $\mathrm{H}$ & $\mathrm{M}$ & $\mathrm{H}$ & $\mathrm{SEM}^{1}$ & $\mathrm{~S}$ & $\mathrm{~V}$ \\
\hline Eläinten lukumäärä & 8 & 8 & 7 & 8 & & \\
Mureus & 5,6 & 5,1 & 5,2 & 5,9 & $0,13-0,14$ & \\
Mehukkuus & 4,5 & 4,3 & 4,7 & 4,8 & $0,23-0,25$ & & \\
Maku & 4,8 & 4,1 & 4,9 & 5,0 & $0,17-0,19$ & 0 & \\
Konsistenssi & 8,5 & 9,0 & 8,2 & 8,0 & $0,44-0,48$ & & $*$ \\
$\mathrm{pH}^{3}$ & 5,52 & 5,59 & 5,57 & 5,54 & $0,011-0,012$ & \\
\hline
\end{tabular}

${ }^{1}$ Keskiarvon keskivirhe.

${ }^{2}$ о $\mathrm{P}<0,10$; * $\mathrm{P}<0,05$; ** $\mathrm{P}<0,01$; *** $\mathrm{P}<0,001$.

${ }^{3} \mathrm{AH}: \mathrm{n}=7$

Taulukko 6. Arvopalojen ja talin saanto (kg).

\begin{tabular}{|c|c|c|c|c|c|c|c|c|}
\hline \multirow{2}{*}{$\begin{array}{l}\text { Säilörehu, (S) } \\
\text { Väkirehun valk.pitoisuus, (V) }\end{array}$} & \multicolumn{2}{|c|}{ A } & \multicolumn{2}{|c|}{ B } & \multirow[b]{2}{*}{ SEM $^{1}$} & \multicolumn{3}{|c|}{ Merkitsevyys $^{2}$} \\
\hline & M & $\mathrm{H}$ & M & $\mathrm{H}$ & & $\mathrm{S}$ & $\mathrm{V}$ & $\mathrm{S} * \mathrm{~V}$ \\
\hline Eläinten lukumäärä & 8 & 8 & 7 & 8 & & & & \\
\hline Ulkopaisti & 18,1 & 18,3 & 17,4 & 17,7 & $0,24-0,26$ & $\mathrm{o}$ & & \\
\hline Sisäpaisti & 11,8 & 11,6 & 11,1 & 11,4 & $0,40-0,43$ & & & \\
\hline Kulmapaisti & 10,7 & 10,5 & 10,1 & 10,2 & $0,09-0,10$ & $*$ & & \\
\hline Paahtopaisti & 5,5 & 5,9 & 5,5 & 5,4 & $0,21-0,23$ & & & \\
\hline Ulkofile & 10,5 & 10,0 & 10,3 & 10,4 & $0,38-0,41$ & & & \\
\hline Sisäfile & 4,1 & 4,0 & 3,9 & 3,9 & $0,11-0,12$ & & & \\
\hline Entrecote & 5,6 & 6,3 & 5,5 & 5,8 & $0,27-0,29$ & & & \\
\hline Tali & 35,2 & 33,7 & 33,4 & 35,4 & $0,83-0,89$ & & & \\
\hline Yhteensä & 101,5 & 100,2 & 97,2 & 100,0 & $0,88-0,95$ & $\mathrm{O}$ & & \\
\hline
\end{tabular}

${ }^{1}$ Keskiarvon keskivirhe.

${ }^{2}$ о $\mathrm{P}<0,10$; * $\mathrm{P}<0,05$; ** $\mathrm{P}<0,01$; *** $\mathrm{P}<0,001$.

\section{Johtopäätökset}

Kaikkien sonnien kasvu oli koko kokeen ajan erinomainen. Hyvän säilörehun merkitys lihanaudan tehokkaassa kasvatuksessa korostui ja D-arvon nousu hyvästä 70 \%:sta viidellä \%-yksiköllä paransi sonnien kasvua vielä huomattavasti. Väkirehun valkuaispitoisuus ei tässä kokeessa vaikuttanut tuotantotuloksiin eikä ruhojen rasvaluokkiin. Väkirehun korkeammalla valkuaispitoisuudella saattaa olla kasvua parantava vaikutus, mikäli käytössä on heikon D-arvon omaava säilörehu. Tästä johtuen tiloilla kulloinkin syötettävän säilörehun analysointi on välttämätöntä oikean väkirehutäydennyksen toteuttamiseksi. Kokeen tulokset ovat sovellettavissa myös luomulihantuotantoon. Väkirehun annostus toteutettiin siten, että se täytti luonnonmukaisen tuotannon vaatimuksen väkirehu:karkearehu-suhteesta (40:60). Myös eläinten alkukasvatus, emon kanssa ensimmäiset kuusi kuukautta, ja loppukasvatusolosuhteet täyttivät luonnonmukaisen tuotannon edellytykset. Kuten monissa aiemmissa kokeissa, ruokintojen vaikutukset lihan aistinvaraiseen laatuun olivat marginaaliset. Lieneekin niin, että lihan syöntilaatuun vaikuttavat lihan marmoroitumisen ja onnistuneen raakakypsytyksen lisäksi eniten valmistuksen yhteydessä tapahtuvat vaiheet tai virheet.

Kiitokset Rehuraisio Oy:Ile kokeeseen toimitetusta valkuaisrehusta, Kuopion Lihankunnan leikkaamon henkilökunnalle sekä MTT:n emolehmänavetan EMO-tiimille kokeen huolellisesta toteutuksesta.

\section{Kirjallisuus:}

Aronen, I., Toivonen, V., Ketoja, E. \& Öfversten, J. 1992. Beef production as influenced by stage of maturity of grass for silage and level and type of supplementary concentrates. Agric. Sci. Finl. 1:441-459.

European Commission. 1971. Commission Directive 71/250/EEC. Determination of ash which is insoluble in hydrochloric acid. Official Journal No L 155/13, 30-31 (Method B).

Friedel, K. 1990. Die Schätzung des energetischen Futterwertes von Grobfutter mit Hilfe einer Cellulasemethode. [The estimation of the energetic feeding value of roughages by means of cellulase method]. Wissenschaftliche Zeitschrift Universitet Rostock, N-Reihe 39, 78-86. 
Kuoppala, K., Rinne, M., Nousiainen, J. \& Huhtanen, P. 2004. Säilörehun ensi- ja jälkikasvun korjuuajan sekä väkirehutäydennyksen vaikutus lypsylehmien maidontuotantoon. In: Toim. Anneli Hopponen ja Marketta Rinne. Maataloustieteen Päivät 2004, 12.-13.1.2004 Viikki, Helsinki [:esitelmät ja posterit]. Suomen maataloustieteellisen seuran tiedote 19: 6 p.

http://www.agronet.fi/maataloustieteellinenseura/julkaisut/esi04/ti54.pdf. Julkaistu 5.1.2004

Manninen, M., Holma, M., Jauhiainen, L. \& Suvitie, M. 2004. Väkirehun kasviöljyn ja E-vitamiinin vaikutus naudanlihan koostumukseen. In: Toim. Anneli Hopponen ja Marketta Rinne. Maataloustieteen Päivät 2004, 12.13.1.2004 Viikki, Helsinki [:esitelmät ja posterit]. Suomen maataloustieteellisen seuran tiedote 19: 4 p. http://www.agronet.fi/maataloustieteellinenseura/julkaisut/posterit04/kr12.pdf . Julkaistu 5.1.2004

Morris T.R. 1999. Experimental Design and Analysis in Animal Sciences. CABI Publishing, Wellington, UK. $134 \mathrm{p}$.

MTT. 2004. Rehutaulukot ja ruokintasuositukset 2004: märehtijät - siat - siipikarja - turkiseläimet - hevoset, MTT. MTT:n selvityksiä 86. 82 s. ISBN 951-729-939-7 (verkkojulkaisu). Verkkojulkaisu päivitetty 31.12.2004. SAS. 1999. SAS/STAT User's Guide, Version 8, Cary, NC: SAS Institute Inc. 3809 p.

Rinne, M. 2000. Influence of the timing of the harvest of primary grass growth on herbage quality and subsequent digestion and performance in the ruminant animal. Helsingin yliopiston kotieläintieteen laitoksen julkaisuja 54: 42 p. + 5 encl. Diss.: Helsinki: Helsingin yliopisto, 2000. (Väitöskirja). http://ethesis.helsinki.fi/julkaisut/maa/kotie/vk/rinne/ 2000-12-12.

Van Soest, P.J., Robertson, J.B. \& Lewis, B.A. 1991. Methods for dietary fiber, neutral detergent fiber and nonstarch polysaccharides in relation to animal nutrition. J. Dairy Sci. 74: 3583-3597. 